Kansas State University Libraries

New Prairie Press

Academic Chairpersons Conference

35th Academic Chairpersons Conference,

Proceedings

\title{
Working With a Unionized Faculty
}

John R. Hamilton Jr

Park University, john.hamilton@park.edu

Follow this and additional works at: https://newprairiepress.org/accp

Part of the Educational Leadership Commons, and the Higher Education Administration Commons (c) (1) (-)

This work is licensed under a Creative Commons Attribution-Share Alike 4.0 License.

\section{Recommended Citation}

Hamilton, J.R. (2018). Working with a unionized faculty

This Event is brought to you for free and open access by the Conferences at New Prairie Press. It has been accepted for inclusion in Academic Chairpersons Conference Proceedings by an authorized administrator of New Prairie Press. For more information, please contact cads@k-state.edu. 


\section{Workshop Proposal for The 2018 Academic Chairs Conference}

\section{Title of Presentation:}

Working with a Unionized Faculty

\section{Presenter:}

John R. Hamilton, Jr, Ph.D.

Associate Professor of Criminal Justice Administration

Park University

8700 N.W. River Park Dr.

Parkville, MO 64152

(816) 584-6302

john.hamilton@park.edu

\section{John R. Hamilton, Jr., Ph.D.}

Dr. John Hamilton is an Associate Professor of Criminal Justice at Park University in Parkville, Missouri. Prior to his appointment to the faculty at Park University in 2003 he served $261 / 2$ years with the Kansas City, Missouri Police Department where he retired at the rank of Major. At the time of his retirement, Dr. Hamilton served as the division commander for the North Patrol Division, a position he held for over 4 years. Dr. Hamilton holds a Bachelor of Arts degree in Psychology from the University of Kansas, a Master of Public Administration degree from the University of Missouri-Kansas City, and an Interdisciplinary Ph.D. in Public Administration and Adult Education from the University of Missouri-Kansas City, and a Graduate Certificate in Dispute Resolution from Missouri State University. Dr. Hamilton currently serves as a negotiator for the Park University Faculty Federation and was the Local President of the Faculty Federation of Park University for eight years. He

also serves on the Office of Community Complaints Advisory Council for the Kansas City, Missouri Police Department and is a co-author of Community Justice, $2^{\text {nd }}$ ed. Published by Routledge.

\section{Presentation Theme:}

Working with Faculty and Administration 


\begin{abstract}
:
Newly appointed supervisors are often concerned when they must oversee the work of employees who are members of a union. This workshop provides some basic information about unions and tips to being a good supervisor or manager in a union environment. The information is appropriate for Chairpersons and Deans.
\end{abstract}

\title{
Keywords:
}

Unions, supervision, due process, accountability, documentation and counseling

\section{Presentation documents:}

Included with this proposal is a draft Power Point presentation that would be used in the workshop. The presentation could be an interactive presentation or a best practices presentation.

This workshop would be appropriate for Chairpersons who will be supervising faculty and/or staff who are members of a Bargaining Unit represented by a union. The information provided could also be helpful to persons at the level of Associate Dean or Dean since they would be in a supervisory role over the employees. The objective of the workshop is to provide Chairpersons with useful tools to help them in their supervisory interactions with faculty members and/or staff members who may be member of a Bargaining Unit represented by a faculty. There will also be some basic information about union operations and Collective Bargaining Agreements shared because many members of Bargaining Units are not familiar with this information and the Chairpersons will need to have some basic understanding of this information so they do not violate any of the agreements that are in place.

The tentative presentation order is the disseminating of information via Power Point slides and any additional handouts provided by the presenter. After the information is shared, two to three scenarios or cases will be shared and workshop participants will be invited to share in commenting on how to handle the situations based upon the information that was presented. Questions and the sharing of experiences from the participants will also be encouraged. 